
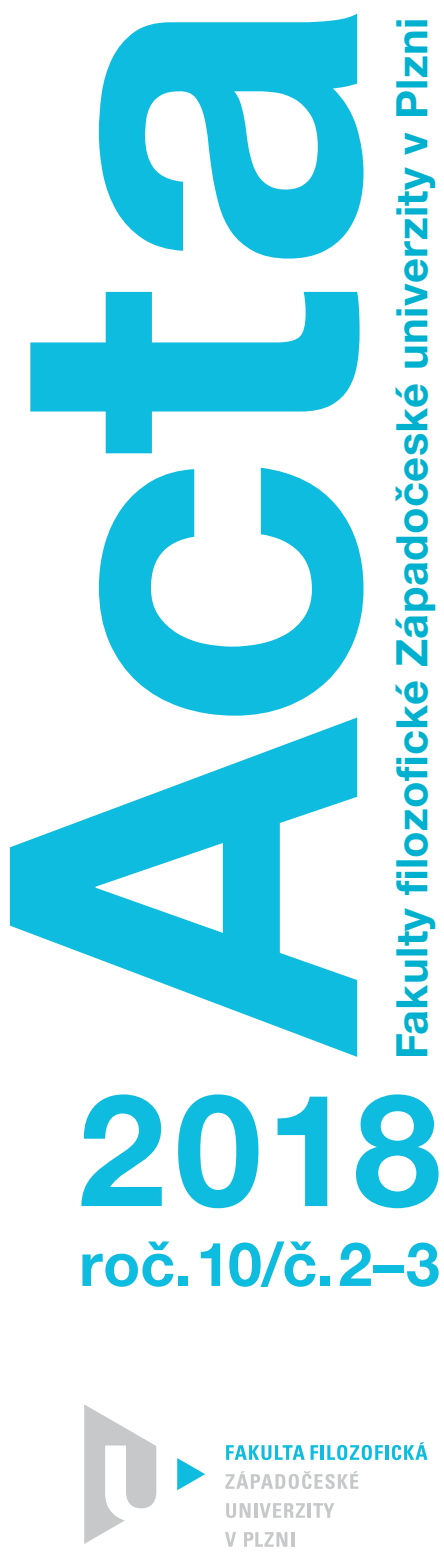


\title{
JAK LEXÉM BITCOIN OBOHATIL ČESKÝ A FRANCOUZSKÝ JAZYK*
}

Dagmar Koláříková **

\section{How Lexeme Bitcoin Enriched the Czech and French Languages}

\begin{abstract}
Bitcoin, first introduced in 2008, and other virtual currencies (litecoin, ripple, ethereum, dash, etc. - known as "altcoins") are a phenomenon of the $21^{\text {st }}$ century. When speaking about bitcoins, views on cryptocurrency-related risks and benefits vary significantly. However, in this article, we will not focus on bitcoin here to illustrate how virtual currencies work. The aim of this article is to show how the borrowed Anglicism bitcoin is used in the Czech and the French languages. The purpose of the theoretical framework is to clarify concepts of neologism, Anglicism and internationalism and propose relationships among the concepts in a study. In the practical section, using the word bitcoin, we show how the loanword is used in both languages and how its integration into the language is similar. The main result of the analysis is a list of derived and compound words from the word bitcoin in Czech and French. The article deals with derived and compound words from the point of view of their quantitative evaluation using Aranea web corpora. In this article, we have shown the possibilities of their derivatives and adaptation to the given system of the language.
\end{abstract}

Key words: adaptation, anglicism, bitcoin, borrowed word, Czech language, French language, internationalism, neologism.

DOI: https://doi.org/10.24132/actaff.2018.10.2-3.4

\footnotetext{
*Článek byl vypracován v rámci projektu SGS-2018-039 Lexikálni kreativita francouzštiny 21. století.

**PhDr. Dagmar Kolář́ková, Ph.D., Katedra románských jazyků, Fakulta filozofická, Západočeská univerzita v Plzni, kolariko@kro.zcu.cz.
} 


\section{1. ÚVOD}

Bitcoin a kryptoměny se svými blockchain technologiemi jsou často označovány za revoluční myšlenku. Na počátku je málokdo bral vážně, postupem času však nenápadně zasahují do našich životů a začínají nás ovlivňovat podobně jako před lety počítače a zejména internet.

Princip digitální měny byl publikován již v roce 2008, bitcoinová sít byla ale uvedena do provozu až v roce 2009, kdy se také uskutečnila první bitcoinová transakce. Bitcoin není však zajímavý jen z hlediska technologie, ale také pro svou minulost, nebot jeho zrození je dodnes obestřeno řadou záhad. Není totiž jisté, zda za jeho vznikem stojí jedna osoba nebo celá skupina, která se od samého počátku úspěšně skrývá pod pseudonymem Satoshi Nakamoto. Novináři se sice již mnohokrát snažili vypátrat Nakamotovu totožnost, nebot za sebou zanechal několik stop, jež je zavedly na tři různé kontinenty, přesto dodnes nevíme, o koho se jedná. Pátrání po jeho identitě je podrobně popsáno v knize Bitcoin. Peníze budoucnosti. Historie a ekonomie kryptoměn, stručná příručka pro úplné začátečníky (Stroukal, Skalický 2015: 20-22).

O bitcoinu začaly vysílat televize, psát noviny, časopisy, webové magazíny, na toto téma se konají konference, do studijních programů na vysokých školách byly zařazeny kurzy o bitcoinu a dalších kryptoměnách. Bitcoin ale není jen jedna z kryptoměn, jak uvádí Fillner (2017: 4), „přináši také nové př́ležitosti, ve světě $i$ u nás vznikaji start-up firmy, které vymýšleji nové technologie a služby spojené s jedním z nejrychleji se rozvíjejicích světových byznysư". Bitcoin se tak stále více dostává do povědomí lidí, nebot se ukázalo, že „není jen hračkou pro IT nadšence, ale něčím, co funguje v reálném světě, za co si lze něco koupit" (Stroukal, Skalický 2015: 50).

Za bitcoiny se dnes už dá koupit prakticky cokoliv. Našli se i lidé, kteří se rozhodli přijímat výplatu pouze v bitcoinech. Někteří se také snaží dokázat, že lze žít výhradně za tuto digitální měnu. Stroukal a Skalický uvádějí ve své knize případ Kashmir Hill, reportérky časopisu Forbes, jež žila týden pouze s bitcoinem, tzn. bez tradičních peněz. Cestovala, nocovala a stravovala se výhradně pomocí této kryptoměny, přičemž sama konstatovala, že to není snadné. Přesto se jí podařilo dokázat, že se dá za bitcoiny žít. O svých zážitcích posléze napsala i knihu Secret Money: Living on Bitcoin in the Real World. Podobný nápad měli i novomanželé Austin a Beccy Craigovi. Ti se na svých cestách po světě, kde platili pouze touto měnou, nechali natáčet profesionálními dokumentaristy po dobu 100 dní. Ostatním tak ukázali, že bitcoiny jsou skutečně peníze (Stroukal, Skalický 2015: 47).

Fenoménu virtuální měny bitcoin je tedy v poslední době věnována stále větší pozornost. Pryč je ale doba, kdy byla všeobecně známá pouze tato první kryptoměna. Veřejnost má dnes povědomost o existenci alespoň některých alternativních kryptoměn, takzvaných altcoinů (litecoin, ripple, ethereum, dash aj.), a začíná již rozumět i principům jejich chování a jejich místu na trhu měn, investičních př́ležitostí a technologických start-upů. Lidé začínají bitcoiny nakupovat, směňovat, těžit anebo přjímat ve svých obchodech.

Cílem tohoto článku ale není popsat, jak funguje kryptoměna, jak ji lze získat nebo jak ji používat. Na toto módní téma zde bude nahlíženo výhradně z lexikál- 
ního hlediska. Budou zkoumány novotvary, které vznikly v českém a francouzském jazyce z nutnosti pojmenovat tuto novou skutečnost. Účelem výzkumu je tedy vyhledat slova, jež byla v češtině a ve francouzštině odvozena od základového slova bitcoin, kompozita vzniklá od tohoto slovního základu a případně i některá syntagmata obsahující daný výraz. Srovnání češtiny a francouzštiny v tomto výzkumu je motivováno typologickou růzností obou jazyků. Předpokládáme, že výsledky výzkumu by mohly být ovlivněny omezenějšími možnostmi derivace ve francouzském jazyce a naopak častějším využíváním kompozice jako zposobu obohacování slovní zásoby v tomto jazyce.

Protože byl poslední slovník neologismů v češtině vydán v roce 2004 a historie kryptoměny bitcoin, jak už bylo řečeno, se začala psát až v roce 2008, je jisté, že v tomto slovníku nová pojmenování týkající se bitcoinu nenalezneme. Než se ale nová slova v češtině dostanou do slovníků, jsou zařazena do neologické databáze Neomat. Slovo bitcoin a existence výrazů od něho vytvořených budou tedy nejprve ověřeny v této databázi, dále pak v jazykovém korpusu Araneum Bohemicum III Maximum (Unesco.uniba.sk 2017a), jenž byl vytvořen v rámci výzkumného programu UNESCO Katedry plurilingválnej a multikultúrnej komunikácie Univerzity Komenského v Bratislavě. Stahování dat pro tento korpus proběhlo naposledy v roce 2017, a proto můžeme předpokládat, že v něm novotvary od bitcoinu budou obsaženy. Také pro francouzštinu bude využit jazykový korpus Araneum Francogallicum II Maximum (Unesco.uniba.sk 2017b), který byl realizován v rámci výše zmíněného výzkumného projektu. Jazykové korpusy Univerzity Komenského v Bratislavě byly vybrány proto, že jak pro češtinu, tak i pro francouzštinu je zde $\mathrm{k}$ dispozici korpus o co největším rozsahu (tzv. maximum).

Výskyt takto nalezených neologismů bude ještě ověřen pomocí internetového vyhledávače Google prostým zadáním daného výrazu do vyhledávacího okna. Budeme-li předpokládat existenci dalších odvozenin nebo složenin od lexému bitcoin, jež nebudou zaznamenány $\mathrm{v}$ analyzovaných korpusech, budou tato slova rovněž zadána do vyhledávače Google. Jelikož budeme postupovat intuitivně, je velmi pravděpodobné, že seznam získaných odvozenin a kompozit nemusí být úplný. Vzhledem k tomu, že počet výskytů uváděný vyhledávačem je jen přibližný (a nelze ho tedy považovat za spolehlivý zdroj statistického srovnání), bude v souhrnných tabulkách uveden pouze počet výskytů hledaného výrazu ve výše zmíněných korpusech.

\section{VYMEZENÍ POJMŮ}

První informace o bitcoinu se objevily v roce 2008. Vzhledem k jeho novosti ho lze tedy označit za neologismus. Zároveň se jedná i o anglicismus, nebot byl přejat z angličtiny, kde bit označuje základní datovou jednotku (bit) a coin drobnou minci. Doslovný překlad kompozita bitcoin tedy zní bitová mince. Jelikož se paralelně vyskytuje ve více nepříbuzných jazycích, můžeme ho současně považovat i za internacionalismus. V následující části budou tedy definovány tyto tři pojmy. 


\section{1. NeOlogismus}

V nejjednodušších slovníkových definicích se můžeme dočíst, že neologismus je nové slovo. Tato definice je zřejmě odvozena z etymologie slova neologismus, nebot neos znamená ve starořečtině nový a logos je slovo. Ne každé slovo je ale pro všechny mluvčí nové (například učí-li se cizinec jiný jazyk, mohou být pro něj všechna slova nová), a proto Pruvost a Sablayrolles dodávají, že se jedná o slovo, jež je nové pro větší skupinu mluvčích, nejen pro jednotlivce (Pruvost, Sablayrolles 2003: 3).

Podle Encyklopedického slovníku češtiny je neologismus „lexikální jednotka, která se ve vztahu $k$ existujícím jednotkám slovní zásoby současného jazyka vyznačuje novostí, a to jak z hlediska vzniku, tak z hlediska funkčního (funkčně systémového, komunikačního, stylistického)" (Karlík, Nekula, Pleskalová 2002: 284). Jinou definici najdeme např́klad v České lexikologii, jejíž autoři definují neologismy jako „lexikálni jednotky jistého úseku lexikální zásoby hodnocené z hlediska současných platných jazykových norem ve srovnání s jednotkami běžnými jako nové, uživané a perspektivní" (Čermák, Filipec 1985: 99). Také v Příruční mluvnici češtiny je na neologismy nahlíženo jako na relativně nová slova, která však postupně „př́znak novosti ztráceji, začínaji se vyskytovat ve větši frekvenci a stávaji se platnou součástí lexikálního systému“ (Grepl, Hladká, Jelínek 2008: 95).

Ve francouzském slovníku Le Petit Robert de la langue française se pod heslem néologisme vyskytuje jednoduchá definice „mot nouveau, sens nouveau d'un $m o t$ ", tzn. nové slovo, nový význam slova. Zároveň je zde ale neologismus definován i jako použití nového slova, a to bud' slova vytvořeného anebo získaného derivací, kompozicí, tronkací, zkracováním, výpůjčkou apod., nebo slova již existujícího, ale v novém významu. Autoři slovníku tak rozlišují formální a významový neologismus (Rey-Debove, Rey 2006: 1721). Z toho vyplývá, že předmětem zájmu tohoto článku budou formálními neologismy, nebot v případě bitcoinu a dalších kryptoměn se jedná o novou výpůjčku.

Také Mortureux označuje termínem neologismus nové slovo, které je zároveň schopno se lexikalizovat. A dodává, že za neologismus může být považováno do té doby, než se objeví v obecném slovníku (Mortureux 1997: 105). Zvláště pro francouzskou lexikografii však platí, že nová slova jsou do slovníků zanášena se značným zpožděním. Radimský to vysvětluje snahou vyhnout se „efemérním záležitostem, modním výstřelkưm a politicky nepřijatelným výpưjčkám a kalkưm" (Radimský 2003: 15). Je ale obtížné stanovit jednoznačnou hranici, kdy neologismus přestává být neologismem. Ztráta příznaku novosti souvisí především se zevšedněním slova.

Jak už bylo uvedeno, neologismy vznikají nejčastěji z nutnosti pojmenovat novou skutečnost, např́klad v tomto článku zkoumaný výraz bitcoin byl vytvořen jednak jako pojmenování virtuální měny, jednak jako název pro platformu, díky níž je tato měna vytvářena. Neologismy mohou být ale i výsledkem záměrného hledání neotřelého výrazu. Jak uvádí Martincová, neologismy jsou ,projevy a výsledky jazykové kreativity a také prostředky nepřetržité regenerace, rekonstrukce a stabilizace slovní zásoby" (Martincová 2005: 7). Takto vzniklé neologismy jsou často 
označovány za autorské ${ }^{1}$ a jsou typické především pro umělecký styl. Mohou se ale objevit např́iklad i v médiích.

\subsection{Anglicismus a Jeho adaptace V PŘejímacím Jazyce}

Také k problematice anglicismů a jejich adaptace v češtině a ve francouzštině se již vyslovila celá řada lingvistů. Obecně lze říci, že anglicismus je anglický výraz přejatý do jiného jazyka. Ve slovnících však najdeme podrobnější definice tohoto slova. Většina českých slovníků definuje anglicismus shodně jako „jazykový prvek prejatý z angličtiny do jiného jazyka n. podle angličtiny $v$ něm vytvořený " (Kraus 2005: 54).

Francouzské výkladové slovníky (např́klad Le Petit Robert de la langue française) považují za anglicismus „emprunt à l'anglais“, tzn. výpůjčku z angličtiny (Rey-Debove, Rey 2005: 95). V elektronickém slovníku Le Trésor de la langue française informatisé je anglicismus definován jako: „Mot, sens ou tour syntaxique anglais introduit dans le vocabulaire ou la syntaxe d'une autre langue" (TLFi 2018: nestr.), tj. slovo, význam nebo syntaktický obrat, který z angličtiny pronikl do slovní zásoby a syntaxe jiného jazyka.

Existují různé klasifikace anglicismů. Například Fridrichová je podle québeckého slovníku anglicismů Colpron dělí na sémantické, lexikální, syntaktické, morfologické, fonetické a grafické (Fridrichová 2013: 42-43). Podle této klasifikace patří bitcoin mezi lexikální anglicismy, nebot se jedná o výpůjčku v její původní anglické podobě.

Přejímání a adaptace lexémů z angličtiny je proces, který má různé fáze a jehož průběh může být ovlivněn řadou faktorů. Podle Nového akademického slovníku cizích slov je termín adaptace $\mathrm{v}$ lingvistice chápán jako „proces zdomácňování (počeštování) cizích jazykových prostredkü“ (Kraus 2005: 21). Tento proces probíhá v různých jazykových rovinách, podle nichž lze formální přizpůsobování jazykových prostředků rozdělit na adaptaci výslovnostní (ortoepickou), grafickou (ortografickou), tvaroslovnou (morfologickou) a významovou (sémantickou) (Svobodová 2009: 44-47). Adaptace grafické stránky je progresivní proces. Slovo je obvykle nejprve přejato s původním pravopisem, později k němu vzniká česká varianta a poté se počeští (Svobodová 2013: 7). Tvaroslovná adaptace spočívá v tom, že slovo je přiřazeno do jednotlivých deklinačních typů a jsou k němu přidávány tvarotvorné sufixy (Svobodová 2007: 50). Důkazem toho, že slovo zdomácnělo, jsou i jeho odvozeniny a složeniny (Čermák, Filipec 1985: 126), což znamená, že dochází k adaptaci slovotvorné. Morfologicko-slovotvorná adaptace nevyžaduje nutně adaptaci výslovnostní a grafickou. Dokladem toho je i zkoumaný lexém bitcoin.

Otázkou, zda anglicismy ortograficko-ortoepicky počeštovat nebo zachovat jejich původní podobu, se zabýval Rejzek ve své studii „K formální adaptaci anglicismů“. Uvádí, že „anglicismus v pưvodni pravopisné podobě pưsobí v českém textu cizorodě a je pro uživatele neznalého angličtiny foneticky neprůhledný. Naopak zastánci pưvodního pravopisu argumentuji tím, že se počeštěním stírá internacionál-

${ }^{1} \mathrm{O}$ bohatém jazyku Arundhatí Royové, oplývajícím autorskými neologismy, se zmiňuje např́íklad Mišterová (2017: 151). 
nost lexému [...], jeho identifikační podoba a že se do českého pravopisu dostávají skupiny hlásek nezvyklého, expresivního charakteru (aj, ej)“ (Rejzek 1993: 26-30).

Jak vyplývá z této definice, anglicismy často fungují zároveň i jako internacionalismy, o nichž bude pojednáno v následující podkapitole.

\subsection{INTERNACIONALISMUS}

Nový encyklopedický slovník češtiny online definuje internacionalismus z hlediska slovní zásoby současných jazyků jako „slovo, výraz (též frazeologický) vyskytující se paralelně ve více jazycích (nepříbuzných nebo ne blízce příbuzných) určitého jazykového, kulturního areálu“ (Martincová 2017: nestr.). Vyznačuje se grafickou a morfologickou blízkostí a obsahovou shodou, jež „zahrnuje významovou shodu, stylistickou blizkost a relativně blízkou komunikační a funkční platnost" (Buzássyová 2010: 115).

Čermák chápe internacionalismy jako slova, která se vyskytují ve většině západoevropských jazyků, nebo jako slova zejména z vědecké oblasti, jejichž základ je často řecko-latinský a jež jsou užívána jako termíny (Čermák 2010: 204). Charakteru internacionalismů nabývají dnes ale i slova přejímaná z jednotlivých národních jazyků, př́ikladem může být italská hudební terminologie, anglická sportovní a počítačová terminologie aj. (Grepl, Hladká, Jelínek 2008: 102). Jejich výhodou je mezinárodní srozumitelnost a mnohdy i větší výstižnost oproti jejich českým a francouzským ekvivalentům.

Běžné francouzské slovníky však nedefinují internacionalismus z hlediska jazykového, ale pouze jako doktrínu, podle níž jsou různé národní zájmy podřízeny nadnárodním zájmům. Pokud francouzsky píšící autoři definují tento pojem jako internationalismes (případně mots internationaux), jejich definice se výrazně neliší od definic v češtině.

Na základě podobnosti (u výpůjček a internacionalismů) nebo nepodobnosti formy a obsahu rozlišuje Šabršula tři typy vztahů mezi slovy a pojmenováními srovnávaných jazyků. První skupinu tvoří vocabula cognata, tzn. slova, jež mají stejnou nebo podobnou formu i obsah (např. ve francouzštině lettre - v angličtině letter). U druhé skupiny slov, která nazývá cognata partim, je shoda významu pouze částečná (ve francouzštině $\operatorname{dogue}=\operatorname{dog} a, \mathrm{v}$ angličtině $\operatorname{dog}=p e s, \operatorname{dog} a$, ale i chlapík, trámová skoba). Poslední skupinou jsou cognata diversificata, u nichž fonetická podoba zůstává stejná, ale liší se svým významem (phycisien - fyzik a physician - lékař). S touto skupinou souvisí i tzv. faux-amis (Šabršula 1983: 70).

Pro přejímání cizích slov, dnes zejména anglicismů, existují různé důvody. Jedním z důvodů může být to, že daný výraz nemá v přejímacím jazyce vhodný jednoslovný ekvivalent, který by ho nahradil. Dalším důvodem je i fakt, že se jedná o internacionální termín z určité odborné sféry, nejčastěji z oblasti ekonomiky či burzovních obchodů. Z toho logicky vyplývá, že přejatý termín bitcoin má v češtině i ve francouzštině své opodstatnění.

Cílem následujícího výzkumu je najít odpověd' na otázku, do jaké míry anglicismus bitcoin v obou jazycích zdomácněl. 


\section{TeRminOLOGIE VIRTUÁLNÍCH MĚN}

Pro měny typu bitcoin se používají různé souhrnné názvy - digitální měna, kryptomèna, elektronická měna, digitální peníze, elektronické penize, e-peníze aj. Oficiální právní dokumenty vypracované orgány EU však používají pojem virtuální měna (virtual currency, ve francouzštině monnaie virtuelle). V tomto článku však budou použity i další názvy, jako jsou kryptoměna (cryptocurrency, ve francouzštině cryptomonnaie, crypto-monnaie / monnaie cryptographique) nebo digitální měna (digital currency / monnaie digitale). Protože se však již termín kryptoměny nezdá být dostatečně přesný pro popsání všech instrumentů spojených se sledovaným fenoménem, byl zaveden i pojem kryptoaktiva (crypto-assets, ve francouzštině crypto-actifs). Podle Journal officiel bychom ale ve francouzštině měli správně používat termín cybermonnaie, nebot 23. května 2017 zde byl vydán nový seznam slovní zásoby z oblasti informatiky, v němž byly navrženy francouzské ekvivalenty $\mathrm{k}$ přejatým termínům $\mathrm{z}$ angličtiny. Komise pro obohacování francouzského jazyka (Commission d'enrichissement de la langue française) doporučuje místo cryptocurrency používat cybermonnaie a uvádí, že jednou z nejdůležitějších kybernetických měn je právě bitcoin (Légifrance 2018).

Virtuální měny nejsou všechny stejné, navíc jich dnes existuje již několik tisíc. Jak už bylo ale několikrát řečeno, v tomto článku bude pozornost věnována především měně bitcoin. Cílem prováděného výzkumu bude zjistit, do jaké míry je tento lexém adaptován $\mathrm{v}$ českém a francouzském jazyce a jaké je př́padně jeho rozššření v obou zkoumaných jazycích.

\subsection{Definice LeXému bitcoin V ČeskÝCh a fRANCOUZSKÝCh SLOVNÍCích}

Bitcoin a celé odvětví kryptoměn má své př́znivce i své odpưrce, faktem ale zůstává, že se o něm čím dále tím více hovoří, at už ve smyslu největšího fenoménu moderní internetové doby nebo největší bubliny 21 . století. Pro většinu lidí se tedy už nejedná o zcela neznámý pojem, bitcoin se stal součástí jejich běžné slovní zásoby.

Důležitým momentem v procesu adaptace výpůjček je i jejich zařazení do slovníku. Vzhledem k novosti termínu bitcoin bylo možné předpokládat, že tento lexém nebude zaznamenán $\mathrm{v}$ knižních podobách výkladových slovníků zkoumaných jazyků. Z hlediska češtiny zejména proto, že všeobecné výkladové slovníky i speciální slovníky neologismů u nás nejsou často vydávány a poslední slovník neologismů v češtině vyšel ještě před vznikem slova bitcoin (Martincová 2004). Oddělení současné lexikologie a lexikografie Ústavu pro jazyk český AV ČR sice od roku 2012 pracuje na Akademickém slovníku současné češtiny, ale zveřejněna byla zatím jen pracovní verze hesel písmene A. I když je možné předpokládat, že dojde $\mathrm{k}$ zařazení lexému bitcoin do tohoto slovníku, nebot,, jak bude uvedeno dále, již figuruje v databázi Neomat, ale s jistotou to tvrdit v současné době nelze. a jak už bylo v článku uvedeno, pro francouzskou lexikografii obecně platí, že nová slova jsou do slovníků zanášena se značným zpožděním. U francouzštiny se však předpoklad absence lexému bitcoin ve slovníku nepotvrdil, tento anglicismus byl do slovníků Larousse a Le Petit Robert de la langue française zařazen již v roce 
2015. ${ }^{2}$ Definici slova bitcoin jsme našli i v Dictionnaire des anglicismes z téhož roku, jehož autorem je Henri Goursau.

Nejjednodušší definice tohoto pojmu figurují v české a francouzské verzi internetového slovníku Wiktionary. Wikislovník definuje bitcoin jako „virtuální měnu s mezinárodní platnosti " a uvádí i zkratky BTC - zažitý kód měny bitcoin a XBT - ISO kód měny bitcoin (Wikislovník 2017). Ve Wiktionnaire, francouzské verzi tohoto slovníku, se vyskytuje následující definice: „Monnaie numérique d'échange chiffrée et décentralisée internationale" (tj. decentralizovaná digitální měna založená na šifrování). Jsou zde rovněž uvedeny výše zmíněné zkratky kódů BTC a XBT. Překvapující bylo zjištění, že podle francouzské verze slovníku je termín bitcoin řazen do oboru numismatiky (Wiktionnaire 2018). Jednoduchou definici bitcoinu ve francouzštině najdeme např́klad i v internetovém slovníku Reverso Dictionnaire, podle níž se jedná o internetovou digitální měnu (Reverso-Softissimo 2017).

Mnohem podrobnější definice bitcoinu přinášejí slovníky v knižních podobách. Nejvíce definic figuruje v již zmíněném Dictionnaire des anglicismes. Bitcoin je zde nejprve definován jako internetová platební sít a peněžní jednotka používaná v tomto platebním systému, dále jako internetová měna, název virtuální měny, digitální měna pro on-line transakce, digitální měna a kryptoměna (Goursau 2015: 31).

Le Grand Larousse illustré 2016 definuje bitcoin jako „unité monétaire d'un système de paiement virtuel permettant à une communauté d'utilisateurs d'échanger entre eux des biens et des services sur Internet; ce système de paiement", tj. platební jednotka virtuálního platebního systému, který umožňuje komunitě uživatelů směnu statků a služeb na internetu; tento platební systém (Kolektiv 2015: 161). Z této definice vyplývá, že měna bitcoin je závislá na specifické virtuální komunitě.

Francouzský slovník Le Petit Robert de la langue française 2017 označuje bitcoin jako marque déposée (ochranná známka) a uvádí následující definici: „Unité monétaire en usage sur Internet, indépendante des réseaux bancaires et liée à un système de cryptage qui enregistre toutes les transactions effectuées avec chaque unité“, tzn. měnová jednotka na internetu, nezávislá na bankovní síti a napojená na šifrovací systém, který zaznamenává všechny transakce provedené s touto jednotkou (Rey-Debove, Rey 2016: 261).

Tyto definice se nejvíce blíží definicím bitcoinu v knižních nebo internetových odborných publikacích o kryptoměnách, nebot v nich je bitcoin definován také jako „decentralizovaná (P2P) sít v internetu, spravujicí historii platebních transakcí mezi svými uzly". Zároveň je zde 1 bitcoin (BTC) považován za základní jednotku takové transakce (Stroukal, Skalický 2015: 163).

Tyto jeho dva významy jsou většinou rozlišeny malým a velkým počátečním písmenem. $\mathrm{V}$ případě jednotky měny se píše bitcoin $\mathrm{s}$ malým písmenem, podobně jako česká koruna nebo americký dolar, jedná-li se o název decentralizovaného platebního systému, uvádí se s velkým počátečním písmenem (Bitcoin). Toto rozlišení je dodržováno i v tomto článku. Jelikož je zde nahlíženo na bitcoin jako na

\footnotetext{
${ }^{2}$ Do nejprestižnějšího a nejobsáhlejšího slovníku angličtiny The Oxford English Dictionary byl pojem zařazen dokonce již v roce 2013 (Soukup 2013).
} 
jednotku měny, je zde důsledně aplikována varianta s malým písmenem (bitcoin). Ve zkoumaných jazykových korpusech lze ale nalézt i další ortografické varianty. V jazykovém korpusu Araneum Bohemicum III Maximum byla přibližně 400krát užita pravopisná podoba BitCoin, 50krát BITCOIN a 13krát bitCoin. Ojediněle se vyskytují i další ortografické varianty, jako např́klad BITcoin. V 17 případech byla tato měna pojmenována jako bitcoint/Bitcoint, z toho jen 4krát s malým písmenem.

Analýza francouzského jazykového korpusu Araneum Francogallicum II Maximum rovněž prokázala rozkolísanost pravopisu tohoto slova. Kromě pravopisných variant Bitcoin(s) (6491krát) a bitcoin(s) (6609krát) zde byla 260krát užita ortografická varianta $\operatorname{BitCoin}(s)$ a $35 \mathrm{krát} \operatorname{BITCOIN}(S)$.

\subsection{AdAPtACE LEXÉmU BItCOIN V ČesKÉm JAZYCe}

Z informací uvedených ve Wikislovníku vyplývá, že si v češtině slovo bitcoin zachovává původní grafickou i výslovnostní podobu /bitkojn/, nedošlo zde tedy k ortografické a ortoepické adaptaci. Na internetu lze sice zaznamenat několik použití počeštěných grafických podob bitkoin a bitkojn, neexistuje však relevantní množství důkazů, jež by potvrdily, že lexém bitcoin se v češtině běžně používá v těchto zdomácnělých podobách. Ve zkoumaném jazykovém korpusu se varianta bitkojn nevyskytovala a grafická podoba bitkoin zde byla zastoupena pouze 5 výskyty.

Již zmíněný Wikislovník řadí slovo bitcoin $\mathrm{k}$ substantivům rodu mužského neživotného a skloňuje ho podle vzoru hrad, což vypovídá o jeho morfologické adaptaci v českém jazyce. V jazykovém korpusu Araneum Bohemicum III Maximum se však také 4krát vyskytoval tvar Bitcoina, který svědčí o skloňování podle vzoru pán. V tomto případě se ale nejednalo o platidlo, nýbrž o pojmenování tvůrce bitcoinu, tzn. pana Bitcoina.

Pro zjištění slovotvorné adaptace zkoumaného termínu bylo pro češtinu využito webové hnízdo Lexiko, jež je komplexním zdrojem lexikografických informací, nebot shromažduje a prezentuje dílčí výsledky práce oddělení současné lexikologie a lexikografie Ústavu pro jazyk český AV ČR. Konkrétně byla použita databáze heslár, obsahující hesláře reprezentativních výkladových slovníků češtiny a hesláře několika slovníků speciálních. Databáze umožňuje také rychle získat informaci, ve kterém slovníku bylo zadané slovo zpracováno. Po zadání slova bitcoin se zobrazilo 9 výsledků vyhledávání. Všechny pocházejí z databáze Neomat. Vedle samotného slova bitcoin $\mathrm{v}$ jednotném a množném čísle to byly výrazy bitcoin peněženka, bitcoincash, bitcoinmat, bitcoinový, bitcointěžar̆, dietbitcoin, předbitcoinový (Ústav pro jazyk český AV ČR 2016: nestr.). Z hlediska slovotvorné adaptace v češtině jsou zajímavé především výrazy bitcoinmat, bitcoin peněženka, bitcoinový, bitcointěžař a predbitcoinový, nebot v případě slov bitcoincash a dietbitcoin se jedná o další přejatá slova, označující jiné druhy kryptoměn. V angličtině, ale i v češtině jsou však obvykle psána jako dvě oddělená slova bitcoin cash a diet bitcoin.

Z uvedených př́íkladů vyplývá, že v češtině jsou slova od slovního základu bitcoin tvořena pomocí derivace, při níž se uplatňuje jak sufixace (bitcoin - bitcoinový), tak i prefixace a sufixace současně (bitcoin - bitcoinový - předbitcoinový). 
Dále dochází ke kompozici, tzn. skládání slov - bitcoinmat vznikl ze syntagmatu bitcoinový bankomat a na základě těžaře bitcoinů bylo vytvořeno kompozitum bitcointěžař. Podle Neomatu se pro vyjádření vztahu používá bud' bitcoin ve funkci adjektiva (bitcoin peněženka), nebo přídavné jméno bitcoinový, utvořené od lexému bitcoin domácím slovotvorným postupem pomocí přípony -ový, jako je tomu i v případě dalších přídavných jmen odvozených od neologismů - internetový, webový, softwarový aj.

Dané výrazy byly také ověřeny v jazykovém korpusu Araneum Bohemicum III Maximum. Adjektivum bitcoinový se zde v různých tvarech vyskytovalo 1226krát. Pro bitcoinmat se zobrazilo 51 výskytů (což je srovnatelné s výskytem syntagmatu bitcoinový bankomat - 52krát, navíc se zde ještě 11 krát vyskytovalo syntagma bitcoinový automat) a pro výraz bitcoin peněženka 313 výskytů, zatímco bitcoinová peněženka se v různých tvarech v korpusu vyskytovala 133krát. Ostatní lexémy (bitcointěžar̆, predbitcoinový, bitcoincash, dietbitcoin) v tomto korpusu nefigurují.

Výsledky z Neomatu sice potvrdily, že došlo k slovotvorné adaptaci lexému bitcoin v češtině, nicméně dvě odvozená a dvě složená slova nejsou dostatečně průkazná pro jeho adaptaci v češtině, a proto byly v jazykovém korpusu a za pomocí Googlu vyhledány další výrazy vytvořené od zkoumaného lexému. Všechny vyhledané odvozeniny a složeniny od lexému bitcoin budou uvedeny v souhrnné tabulce, a to i s rozlišením, zda se jedná o výraz z korpusu nebo z internetu.

Základním předpokladem bylo, že v češtině muselo vzniknout minimálně pojmenování pro uživatele bitcoinů. Ti jsou v podstatě dvojího druhu - těžař $i^{3}$ a koncoví uživatelé, přičemž každý z účastníků může být zároveň těžařem i koncovým uživatelem. Bylo zjištěno, že pro uživatele bitcoinů existují v češtině čtyři různá pojmenování - bitcoinista, bitcoinář bitcoinér a bitcoiňák, jež byla používána především v množném čísle - bitcoinisti, bitcoináři, bitcoinéři a bitcoiňáci, žádné z nich však nebylo užito v ženském rodě. Použití sufixů -ista, -ářr, -ér je logické, nebot tyto přípony tvoří v češtině z podstatného jména jiné substantivum, označující člověka vykonávajícího nějakou profesi nebo činnost. Zejména sufixy -ista a -ér se často přidávají $\mathrm{k}$ podstatným jménům cizího původu. Substantiva zakončená na -ista patří ke vzoru predseda a v 1. pádě množného čísla mají koncovku -é. Podoba s - $i$, jež se vyskytovala u všech nalezených příkladů, je považována za hovorovou. Jména zakončená na -ář náleží ke vzoru muž a v 1. pádě množného čísla mají koncovku - $i$ (bitcoináři), stejně jako substantiva zakončená na -ér, která se skloňují podle vzoru pán (bitcoinérí). Také odvozené substantivum bitcoiňák odpovídá pravidlům tvoření nových slov v češtině, nebot sufix -ák se může rovněž připojovat $\mathrm{k}$ substantivnímu základu. Takto vytvořené substantivum se skloňuje podle vzoru pán a vyjadřuje mimo jiné příslušnost $\mathrm{k}$ určité skupině. Někdy je používáno s expresívním zabarvením. Vedle těchto substantiv vytvořených derivací pomocí zmíněných sufixů -ista, -ářr, -ér lze na internetu i v korpusu zaznamenat také výskyt původního anglického výrazu pro uživatele bitcoinů - bitcoiner, jenž se přizpůsobil českému morfologickému systému a skloňuje se podobně jako bitcoinér podle vzoru pán (bit-

\footnotetext{
${ }^{3}$ Již zmíněný výraz bitcointěžař nebyl nalezen ani pomocí Googlu, v češtině se spíše vžilo pojmenování bitcoin těžar̆ nebo bitcoinový těžar̆, připadně anglicismus miner - jeho nevýhodou je ale to, že označuje nejen člověka provozujícího počítač, který je pomocí internetu spojen s ostatními takovými počítači, ale i samotný počítač, tzn. těžební stroj.
} 
coiner, -a). a proto byl zařazen i do souhrnné tabulky, ačkoliv se nejedná o derivát vytvořený až v češtině.

U již zmíněné odvozeniny bitcoinár došlo navíc k prefixaci sufixovaného substantiva pomocí předpon pro- a anti-, sloužících k rozlišení zastánců bitcoinu, nazývaných pro-bitcoináři, a jeho odpůrců, tj. anti-bitcoinářů. Prefix pro- má v češtině různá východiska, v případě odvozeniny pro-bitcoinář se jedná o latinskou, resp. řeckou předložku/prefix pro-, s významem souhlas/sympatie, a to jako součást cirkumfixu pro- -ář. Počáteční morfém anti-, jenž nese význam stojící, působící proti něčemu, bývá někdy chápán i jako slovní základ (prefixoid), v tomto článku je ale řazen $\mathrm{k}$ předponám. Bylo rovněž zjištěno, že je tento prefix v češtině připojován i k lexému bitcoin ve funkci adjektiva (lze hovořit o tzv. konverzi ${ }^{4}$ ), o čemž svědčí spojení jako anti-bitcoin kampaň, anti-bitcoin propaganda aj., ale také i k adjektivu s příponou -ový (například antibitcoinoví škodiči). Z uvedených příkladů vyplývá, že jsou obvyklé dvě ortografické varianty: se spojovníkem i bez spojovníku. Stejně tomu tak je i u prefixu pro-, který se připojuje k adjektivu bitcoinový rovněž ve dvou pravopisných podobách (pro-bitcoinový i probitcoinový). V př́padě tohoto adjektiva bylo zaznamenáno i použití předpony proti-, jež se obvykle připojuje k adjektivu se základem cizího původu (protibitcoinový) jako náhrada za již uvedený cizí prefix anti-.

$\mathrm{K}$ derivátům na -ista existují v češtině obvykle substantiva se zakončením na -ismus/-izmus. Tato př́ípona se většinou připojuje $\mathrm{k}$ odvozovacímu základu přejatému z cizích jazyků a může být mimo jiné použita i k utvoření názvu nějaké zájmové činnosti nebo i k označení společensky negativního jevu. Vzhledem k rozdílným názorům na bitcoin se dalo předpokládat, že by mohlo slovo bitcoinismus v češtině vzniknout. Jak v jazykovém korpusu, tak i na internetu však nebyl zaznamenán jediný výskyt tohoto výrazu.

Poměrně překvapujícím zjištěním byla existence několika odvozenin pro pojmenování bitcoinu jako platidla. Jedná se o substantivum bitcoiník, vytvořené pomocí sufixu -ik, jenž se často využívá pro integraci přejatých substantiv do deklinačního systému češtiny. Tato př́pona se řadí mezi sufixy zdrobňující, vzniklý výraz bitcoiník tak označuje drobné této kryptoměny. Produktivním deminutivním sufixem je také - $e k$, který se připíná ke kmeni základového maskulina. V češtině tak vzniklo slovo bitcoinek, označující rovněž virtuální minci zkoumané měny. Byl ale zaznamenán i př́ípad použití výrazu Bitcoinek jako zdrobněliny vlastního jména: „,[...] že bych se nedivil, kdyby po Indii a Brazílii běhali mali Blockchainkové, Bitcoinkové a Cryptouškové" (Steemit.com. 2018: nestr.). V jazykovém korpusu se vyskytoval i výraz bitcoinka. Samotný tvar nám může asociovat peněženku na bitcoiny, ale podle kontextu se zřejmě jedná o nový typ platformy pro obchodování s kryptoměnami, jenž byl v angličtině označen jako bitcoinKu, a proto se nejedná v češtině o derivát, ale o adaptovaný anglicismus. Prostřednictvím Googlu bylo ale nalezeno i substantivum bitcoinka, které vzniklo přechýlením z podstatného jména rodu mužského pro označení osoby rodu ženského (jako uživatelské jméno). K označení platidla (papírových peněz) se v češtině také využívá sufix -ovka (bankovka, státovka). Má rovněž funkci adaptační, tzn. že slouží k zařazení přejatých slov

\footnotetext{
${ }^{4}$ Horová (2014: 190) používá také termín nepravá derivace.
} 
do skloňovacího systému češtiny. Pomocí této přípony vzniklo slovo bitcoinovka a z něho byla vytvořena např́klad i složenina padesátibitcoinovka.

Vzhledem k existenci substantiv, jako jsou dolarizace nebo euroizace, bylo možné se domnívat, že v češtině vzniklo také substantivum bitcoinizace, jež by označovalo stav, kdy země na svém území zavede jako legální platidlo bitcoin a k němu př́íslušné sloveso bitcoinizovat, nebot sufix -izovat je rovněž častým stavebním prvkem přejatých slov. Zatímco bylo nalezeno několik článků o bitcoinizaci Venezuely či bitcoinizaci světové ekonomiky, existenci slovesa bitcoinizovat nelze potvrdit, nebot ani v korpusu, ani na internetu nebyl zaznamenán jediný výskyt. Uvedené substantivum bylo také několikrát použito s prefixem hyper- ${ }^{5}$ který je často stavebním prvkem přejatých slov a mimo jiné vykazuje zvýšenou míru něčeho (např́íklad se hovoří o hyperbitcoinizaci světa). V obou případech je ale těžké posoudit, zda se jedná o deriváty vytvořené na základě češtiny nebo o adaptované přejímky z angličtiny, nebot obě slova $\mathrm{v}$ angličtině existují.

Výše zmíněná databáze Neomat prokázala existenci adjektiv bitcoinový a předbitcoinový. V češtině se však od substantiv tvoří adjektiva vyjadřující vztah nejen pomocí již zmíněného sufixu -ový, ale i přidáním přípony -ní. Bylo ověřeno, že takto vytvořené adjektivum konkuruje v některých případech sufixu -ový, nebot byla nalezena syntagmata bitcoiní služba i bitcoinová služba, bitcoiní transakce i bitcoinová transakce, bitcoiní peněženka i bitcoinová peněženka, bitcoiní burza i bitcoinová burza aj. Pomocí Googlu bylo ale nalezeno i několik adjektiv zakončených na -ný. Ani takto vytvořené adjektivum neodporuje pravidlům tvoření slov v češtině, nebot i sufix -ný je používán k odvozování adjektiv vyjadřujících vztah (např. bitcoiné sítě - sítě týkající se bitcoinu, nabízející bitcoiny apod.).

Při odvozování od substantivního základu lze předpokládat i vznik slovesa, jež by označovalo činnost spojenou s bitcoinem. K tomu se v češtině využívá především sufix -ovat, jehož nejčastější funkcí je právě adaptace cizích slov. Tento předpoklad potvrdil výskyt slovesa bitcoinovat. Přidáním sufixu -ovat k substantivnímu základu mohou vytvořená slovesa nabývat různého významu. V nalezených příkladech bylo sloveso bitcoinovat užito ve významu vytvářet, př́ípadně používat jako nástroj to, co označuje základové substantivum, což dokládá nalezený příklad, kde v úvaze o tom, jakým zpo̊sobem zdanit bitcoiny, čtenář navrhuje zdanit internet, ale zároveň dodává, že by to postihlo všechny, at bitcoinují nebo nebitcoinuji (Hlavenka 2013: nestr.). Na internetu byl ale vyhledán i příklad, v němž bylo sloveso bitcoinovat spojeno s významem nesoucím spíše negativní konotaci: „Už jsme dali světu slovo , tunelovat‘. Ted' zase můžeme, bitcoinovat" - legalizovat $v$ Alze anonymni špinavé obchody" (Beránek 2017: nestr.).

Poměrně překvapující je i zjištění, že od adjektiva bitcoinový bylo v češtině pomocí sufixu -ě utvořeno adverbium prvního stupně bitcoinově, které se vyskytovalo např́klad ve spojeních bitcoinově nejbohatši, vstupné je bitcoinově dobrovolné, u nás to bitcoinově vře aj.

Kryptoměny jsou na obrovském vzestupu, a proto se dalo také předpokládat, že v češtině vznikla i různá kompozita, jejichž jeden element by obsahoval lexém

\footnotetext{
${ }^{5}$ Také slovotvorný prvek hyper- je podobně jako anti- považován bud' za předponu nebo za prefixoid, tj. „slovotvorný prostředek funkčně stojící na rozhraní slovotvorného základu a prefixu" (Furdík 2004: 155), u slova hyperbitcoinizace ho lze ale pokládat za prefix.
} 
bitcoin a druhý by vyjadřoval obrovský až přehnaný zájem o toto platidlo. Analýza jazykového korpusu i vyhledání pomocí Googlu prokázaly výskyt substantiv bitcoinmanie (i bitcoinmánie) a bitcoinmaniak (nesoucí význam posedlý bitcoiny), zatímco předpokládaný výraz bitcoinboom nebyl v této podobě nalezen. Pouze v jednom případě se jednalo o kompozitum, nebot obě lexikální jednotky byly psány se spojovníkem (bitcoin-boom), v ostatních případech byl výraz psán jako dvě oddělená slova. Ne každý je ale maniak do kryptoměn. Existují např́iklad instituce, které se bojí bitcoiny přijímat, a proto vzniklo i kompozitum bitcoinfobie (objevuje se i ve variantě bitcoin-fobie).

V roce 2013 vznikl web bitcoinman.cz, obsahující informace o všem, co se daného tématu týká, tzn. jak se bitcoiny těží, nakupují, prodávají apod. Jak uvádí sám autor projektu, toto pojmenování vzniklo na základě toho, že bitcoin považuje za měnu nezávislého člověka. Tato druhá část přejatých složených slov (-man) však může v češtině označovat i toho, kdo je nadměrně až chorobně něčím posedlý.

Z uvedených příkladů vyplývá, že kompozita jsou tvořena zejména pomocí sufixoidů, ${ }^{6}$ proto je můžeme nazývat sufixoidními kompozity. $\mathrm{V}$ případě složenin s komponentem bitcoin se jedná o prvky cizího původu, přesněji internacionální prostředky latinsko-řecké (-manie, -man, -fobie, -mat). K novějším sufixoidům patří prvky z angličtiny -holik a -gate. Zatímco v angličtině již výraz bitcoinholic existuje, v češtině jeho užití zaznamenáno nebylo. Byl nalezen pouze ojedinělý výskyt kompozita bitcoingate, kde sufixoid -gate označoval aféru spojenou s bitcoinem. Ze složenin vytvořených pomocí prefixoidů bylo do tabulky zařazeno pouze prefixoidní kompozitum milibitcoin, nebot došlo k jeho počeštění.

Ve zkoumaném jazykovém korpusu se vyskytuje celá řada kompozit, jež však byla vytvořena spojením dvou anglických slov (bitcoin-central, bitcoin-dollar, bitcoin-fiat, bitcoin-like, bitcoin-miner, bitcoin-mining, bitcoin-only, bitcoin-positive, bitcoin-related, bitcoin-themed, bitcoinadshare, bitcoinbillionaire, bitcoincharts, bitcoincloud aj.). Tyto tvary prokazují, že nedošlo k jejich adaptaci v češtině, navíc se u nich jednalo o zanedbatelnou frekvenci výskytu, a proto je ani neuvádíme v následující souhrnné tabulce č. 1. Za hapax legomenon ${ }^{7}$ lze označit i složeniny s českým komponentem, které se vyskytují ve zkoumaném jazykovém korpusu: bitcoin-skeptický, bitcoinpeněženka, bitcoin-přebírající.

Z tabulky vyplývá, že většina vyhledaných derivátů a kompozit se vyskytuje nejen v internetových textech, ale i v analyzovaném korpusu. Z 36 uvedených výrazů jsou nejpočetněji zastoupena substantiva, kterých je v tabulce 25, následují adjektiva (9), verba a adverbia jsou zastoupena vždy jen jednou jednotkou. Ze způsobů tvoření převažuje derivace (20 odvozenin), ve 14 případech došlo ke skládání slov, jedenkrát ke konverzi a slovo bitcoiner bylo označeno za adaptovanou výpůjčku.

\footnotetext{
${ }^{6}$ Jedná se o „slovotvorný prostředek funkčně stojící na rozhraní slovotvorného základu a formantu" (Furdík 2004: 158).

${ }^{7}$ Pojmem hapax legomenon zde označujeme slovo, které se vyskytuje v rámci zkoumaného korpusu pouze jedenkrát.
} 


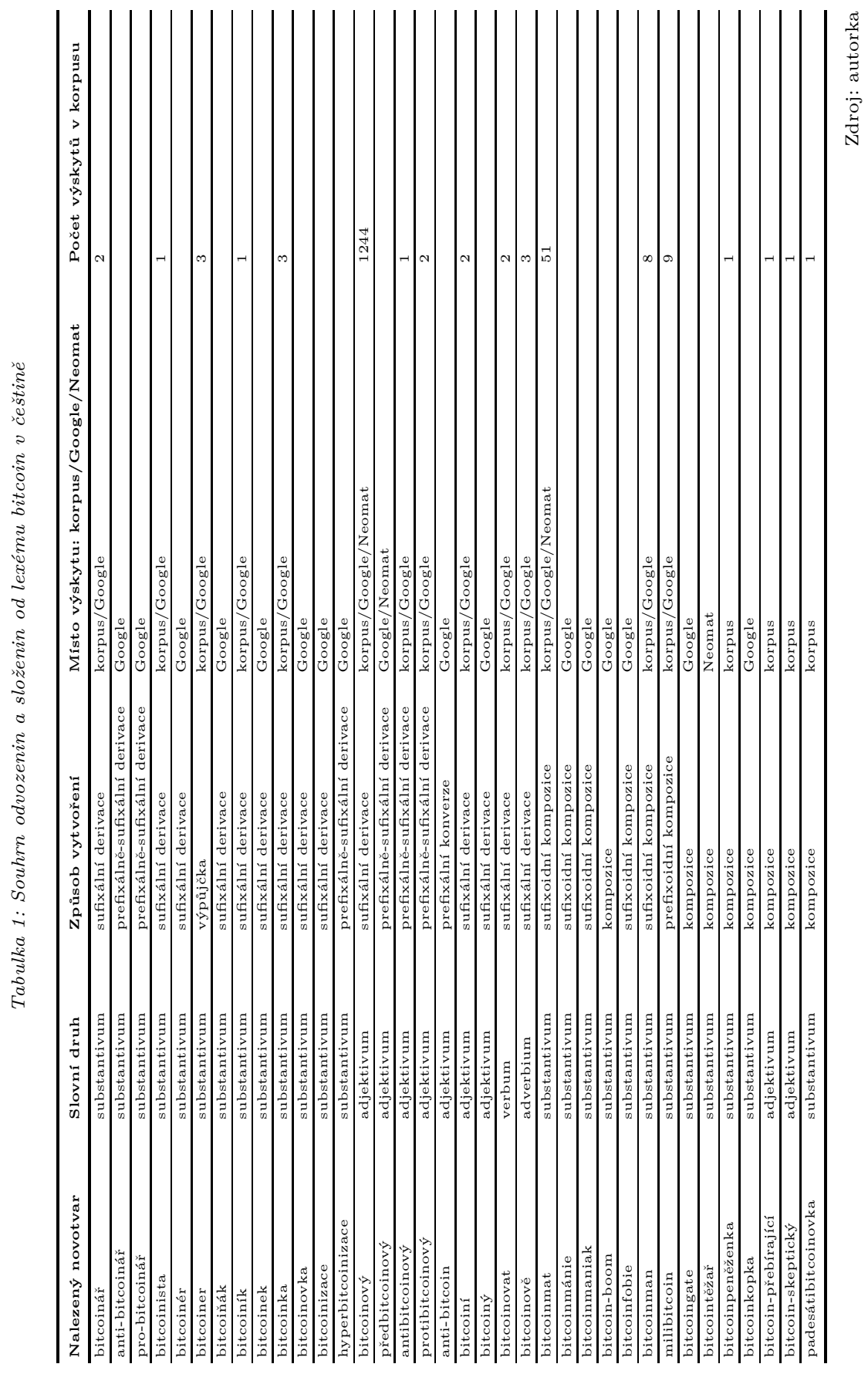




\subsection{AdAPTACE LEXÉmU bitCoIN VE fRANCOUZSKÉM JAZYCE}

Rovněž do francouzštiny bylo slovo bitcoin přjato v původní grafické podobě, což odpovídá současným tendencím ponechávat původní tvary výpůjček, zejména jedná-li se o termín z určité odborné oblasti. Tato grafická podoba je navíc pro francouzštinu přirozená, je zde běžně používána souhláska „c" $\mathrm{s}$ výslovností /k/ (následuje-li po ní „o“) i skupina samohlásek „oi“ (v tomto případě ale s odlišnou výslovností).

Co se týče fonologické adaptace anglicismů, ve francouzštině obvykle existují dvě výslovnostní varianty - původní anglická a pofrancouzštělá. U slova bitcoin je však jen velmi malá pravděpodobnost, že by se ujala francouzská výslovnost /kwẽ/, nebot výraz coin ve francouzštině již existuje (znamená mj. razidlo mincí, punc $)^{8}$ a mohlo by tak dojít $\mathrm{k}$ jejich záměně. I ve francouzštině je tedy bitcoin vyslovován jako /bit.kojn/.

Analyzované francouzské slovníky přiřazují lexém bitcoin $\mathrm{k}$ substantivům rodu mužského, ve vyhledaných příkladech je běžně používán s příslušnými determinanty a přibírá i znak plurálu -s, přizpůsobil se tedy francouzskému morfologickému systému.

Pro prokázání slovotvorné adaptace byl zvolen podobný postup jako v češtině. Také pro francouzštinu byl výzkum nejprve zaměřen na ověření existence odvozenin označujících osobu, jež se zabývá činnostmi spojenými s bitcoinem. Pomocí jazykového korpusu Araneum Francogallicum II Maximum a vyhledávače Google byla nalezena substantiva bitcoineur, bitcoiniste a bitcoinien, vytvořená přidáním francouzských sufixů -eur, -iste a -ien ke slovnímu základu bitcoin. V př́padě -eur a -iste se jedná o substantivní př́pony označující osobu zapojenou do nějaké činnosti. Sufix -ien se nejčastěji připojuje $\mathrm{k}$ propriím s významem př́slušnosti $\mathrm{k}$ něčemu. Kromě těchto odvozenin byl $\mathrm{i}$ ve francouzštině $\mathrm{v}$ některých př́padech použit pro označení uživatele bitcoinů původní anglický výraz bitcoiner, jenž se přizpo̊sobil francouzskému morfologickému systému, nebot se používá se členem, jako tomu bylo v následujícím úryvku: , „[... on peut se demander comment le fisc arrivera à traquer le 'bitcoiner' occasionnel!" (Massonnaud 2014: nestr.). Zatímco v češtině žádné podstatné jméno označující uživatelky bitcoinů zaznamenáno nebylo, ve francouzštině se užívá i tvar ženského rodu od slova bitcoineur - bitcoineuse. Podobně jako v češtině může i ve francouzštině dojít $\mathrm{k}$ prefixaci sufixovaného výrazu, např́klad pomocí prefixu ex- bylo vytvořeno substantivum exbitcoiniste pro označení bývalého bitcoinisty.

Na rozdíl od češtiny, v níž se slovo bitcoinismus nevyskytovalo, byl ve francouzštině zaznamenán ojedinělý výskyt tohoto substantiva (bitcoinisme). Deriváty s touto př́ponou jsou výhradně abstrakta vyjadřující kladný, neutrální, ale často i negativní postoj. Ve vyhledaném př́kladu byl bitcoinisme považován za jakési náboženství. O negativním postoji pak svědčí především výraz anti-bitcoinisme, vytvořený prefixálně-sufixálním způsobem.

$\mathrm{Z}$ adjektiv je poměrně rozšîřené přídavné jméno vytvořené pomocí sufixu -ien. Jak už bylo zmíněno, jedná se o př́ponu, která se ve francouzštině obvykle

${ }^{8}$ Pro účely tohoto článku jsme uvedli významy vztahující se k měně, jinak nejrozšířenějším významem francouzského výrazu coin je s největší pravděpodobností roh nebo kout. 
připojuje k propriím a vyjadřuje př́íslušnost $\mathrm{k}$ místu, původ nebo vztah k něčemu. Byly nalezeny výrazy jako apocalypse bitcoinienne, euphorie bitcoinienne, bulle bitcoinienne, marchés bitcoiniens aj. Méně frekventované je použití př́ídavného jména bitcoineur / bitcoineuse, které se vyskytovalo například v syntagmatu équipe de France bitcoineuse nebo sirènes bitcoineuses. Podobně jako v češtině je lexém bitcoin používán i ve funkci adjektiva a může přibírat různé prefixy, například pro- (les acteurs pro-bitcoins), anti- (l'argumentaire standard anti-bitcoin) nebo inter-(les échanges inter-bitcoins).

Zatímco v češtině byla zjištěna pouze existence substantiva bitcoinizace, ve francouzštině se vyskytuje nejen podstatné jméno bitcoinisation (se stejným významem jako v češtině), ale i sloveso bitcoiniser a jeho zvratná podoba se bitcoiniser. Zmíněné substantivum bylo podobně jako v češtině také opatřeno předponou hyper- (l’hyperbitcoinisation). Jak už ale bylo zmíněno v předešlé části, lze jen těžko prokázat, zda se jedná o deriváty nebo adaptované přejímky z angličtiny.

Vedle slovesa bitcoiniser / se bitcoiniser se na webových stránkách investir.ch vyskytuje také verbum bitcoiner, a to v článku s názvem „Nouveau verbe: «se faire bitcoiner»" (Veillet 2017: nestr.). Nicméně uvedené sloveso lze označit za hapax legomenon, nebot byl zaznamenán pouze tento jediný výskyt. Jeho rozšíření není navíc příliš pravděpodobné vzhledem $\mathrm{k}$ podobnosti s již zmíněným substantivem anglického původu bitcoiner.

Také ve francouzštině došlo k odvození adverbia bitcoinement. Jeho tvar však neodpovídá obecnému pravidlu o tvoření adverbií ve francouzštině, která jsou nejčastěji tvořena od adjektiv připojením sufixu -ment, a to ke tvaru feminina. $\mathrm{V}$ tomto případě byla přípona -ment přidána přímo ke kořenu bitcoin a před ní vložen infix - $e$ - pro usnadnění výslovnosti. Domníváme se, že toto adverbium bylo utvořeno analogicky podle existujícího adverbia amicalement, nebot bylo použito $\mathrm{v}$ korespondenci v pozdravu na rozloučenou.

I ve francouzštině se vyskytují sufixoidní kompozita, jež vznikla podobně jako v češtině připojením řeckých prvků -manie, -man, -phobie k lexému bitcoin (bitcoinmanie/mania, bitcoinmaniac, bitcoinman, bitcoinphobie). Na rozdíl od češtiny se zde nevyskytuje slovo bitcoinmat, což je logické, nebot ani pro bankomat není ve francouzštině používáno kompozitum se sufixoidem -mat. Pro bitcoinmat se ve francouzštině vžilo pojmenování guichet automatique bitcoin (de bitcoins, pour le bitcoin, distribuant des bitcoins apod.). Na druhou stranu zde ale vzniklo sufixoidní kompozitum bitcoinphile, v němž -phile pochází z řeckého -filos (milovník) a nese význam, kdo miluje to, co je vyjádřeno první částí kompozita, v př́ípadě bitcoinphile se tedy jedná o milovníka bitcoinů. Byl zaznamenán i výskyt prefixoidního kompozita s prvkem euro- (un échangeur euro-bitcoin).

Z kompozit byly do tabulky zařazeny složeniny bitcoinland, bitcoincours, bitcoinmonnaie, étalon-bitcoin, hébergeur-bitcoin. Z tohoto výčtu vyplývá, že na rozdíl od češtiny, kde byl bitcoin vždy prvním komponentem složeniny, ve francouzštině může stát i na druhém místě. V současné francouzštině je také hojně rozšśřrené tvoření tzv. mots-valises. Jedná se o lexikální jednotky složené ze dvou komponentů, z nichž jeden či oba vznikly tronkací. Na internetu byly zaznamenány dvě složeniny tohoto typu - bitcoinomie (bitcoin + économie) a bitcoinnerie (bitcoin + connerie / blbina, hovadina). 


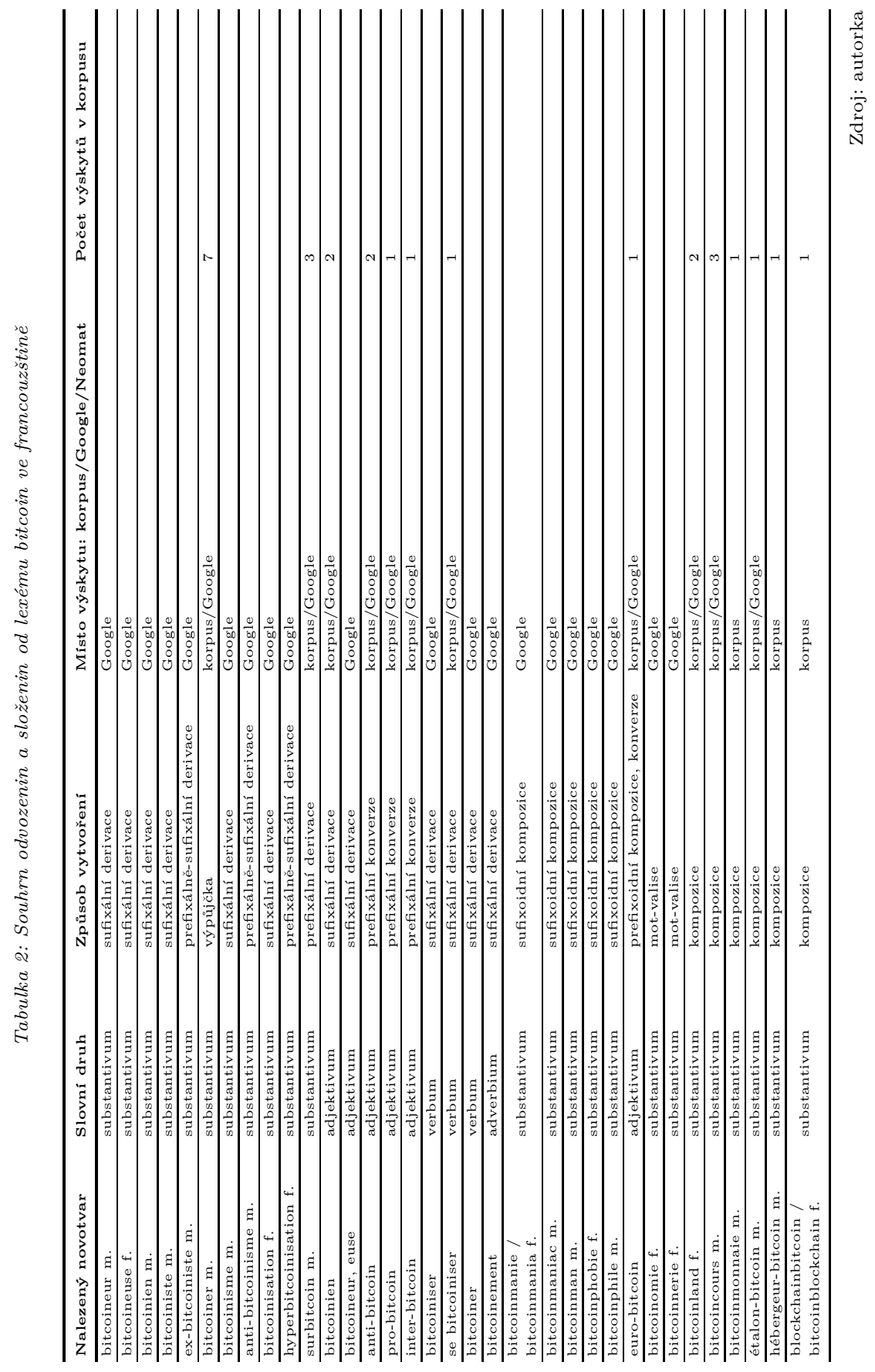


Tabulka č. 2 shrnuje deriváty a kompozita obsahující slovní základ bitcoin, jež byla vyhledána ve zkoumaném korpusu a na internetu. Podobně jako v češtině do ní nebyla vložena různá kompozita nalezená v korpusu, pomocí nichž byly vytvořeny názvy webových stránek nebo internetových portálů (např́iklad achat-bitcoins, bitcoinmagazine, local-bitcoins, Francbitcoins aj.). Ze složenin obsahujících dva anglické komponenty se v tabulce vyskytuje pouze blockchainbitcoin / bitcoinblockchain (potvrzující již zmíněné libovolné postavení komponentu bitcoin ve vzniklých složeninách), nebot toto kompozitum v anglických textech nalezeno nebylo.

Z tabulky vyplývá, že počet vyhledaných výrazů je srovnatelný s češtinou, nebot tabulka obsahuje 34 derivátů a kompozit utvořených ze slovního základu bitcoin. Mezi nimi jsou nejpočetněji zastoupena substantiva (24). Oproti češtině bylo ve francouzštině vytvořeno méně adjektiv (6), ale více sloves (3 - zvratná podoba slovesa bitcoiniser byla vydělena zvlášt, protože nezvratná podoba se v korpusu nevyskytovala). Podobně jako v češtině bylo odvozeno pouze jedno adverbium. Ze způsobů tvoření nových slov je poměr mezi derivací a kompozicí poměrně vyvážený (16krát došlo k derivaci, 14krát ke kompozici), ve třech případech byla uplatněna konverze a substantivum bitcoiner bylo podobně jako v češtině označeno za adaptovanou výpůjčku. Ve francouzštině se však častěji jedná o výrazy, které lze označit za hapax legomenon. Výzkum také prokázal, že v jazykovém korpusu Araneum Francogallicum II Maximum se vyskytovala jen necelá polovina těchto novotvarů.

\section{ZÁvĚr}

Vytvářením nových slov se jazyk vyrovnává s novými vlivy a komunikačními potřebami. Jedním ze způsobů jejich tvoření je přejímání z jiných jazyků. Některé výpůjčky do jazyka rychle přicházejí a brzy ho zase opouštějí. Podobně je tomu i s virtuálními měnami. Jak rychle vznikají, tak rychle také zanikají. Na webové stránce DeadCoins.com, jež pravidelně aktualizuje seznam zkrachovalých kryptoměn, je v současné době evidováno 828 takových platidel (iDNES.cz. 2018). Absurditu situace na trhu zdůrazňují i názvy některých virtuálních měn: jesuscoin, trumpcoin, vodkacoin, sexcoin, bananacoin aj. Pro kupující je někdy obtížné rozpoznat, která platidla byla vymyšlena jako vtip a která jsou podvodná. Také bitcoin prochází různými turbulentními obdobími. Ale i když mu mnozí věštili brzký konec, zatím se nedá říci, že by mizel z burz kryptoměn.

Můžeme proto předpokládat, že lexém bitcoin a jeho deriváty a kompozita nebudou patřit mezi slova efemérní, tj. ta, jež jsou užívána v jazyce jen krátkodobě. Jak už bylo v článku řečeno, bitcoin se v různých jazycích vyskytuje zhruba deset let. Z jazykového hlediska je to poměrně krátká doba na to, abychom k němu mohli zaujmout jednoznačné stanovisko. Získané údaje nám však dovolují vyvodit určité závěry.

Na první pohled se může zdát, že se anglicismus bitcoin více zabydlel ve francouzském jazyce, nebot zatímco do francouzských výkladových slovníků v knižní podobě byly zaneseny různé definice hesla bitcoin již v roce 2015, na přidání tohoto slova do slovníku českého jazyka si musíme ještě počkat. Provedený výzkum však prokázal, že ve francouzštině i v češtině vznikl srovnatelný počet novotvarů 
od kořene bitcoin, které byly utvořeny na základě slovotvorných pravidel daných jazyků. V češtině vzniklo více odvozenin, zatímco ve francouzštině byl počet derivátů a kompozit vyrovnaný. Potvrdil se tak náš původní předpoklad, že výsledky výzkumu by mohly být podmíněny typologickou odlišností obou jazyků.

I když u většiny nově vytvořených výrazů můžeme prozatím hovořit spíše o hapax legomena, tzn. lexikálních prvcích, jež byly vytvořeny pro užití v jednom konkrétním textu, jejich znovuutváření v dalších komunikátech a tím i jejich postupné přetváření v neologismy je velmi pravděpodobné.

V obou jazycích byla od lexému bitcoin vytvořena substantiva, adjektiva, verba i adverbia. Ze substantiv jsou to zejména jména konatelská (bitcoin-ár̆, bitcoin-ista, bitcoin-ér, bitcoiň-ák, bitcoin-er $\times$ bitcoin-eur, bitcoin-iste, bitcoin-ien, bitcoin-er), $\mathrm{v}$ češtině pak i deminutiva ( bitcoin-ik, bitcoin-ek). Adjektiva a slovesa vznikla připojením příslušných českých a francouzských sufixů, pro adjektiva se jedná v češtině o př́pony -ový (bitcoin-ový), -(n)ý (bitcoin-ý) nebo -(n)í (bitcoin-í) a ve francouzštině -ien (bitcoin-ien) a -eur (bitcoin-eur). Slovesa byla vytvořena v češtině pomocí sufixu -ovat (bitcoin-ovat) a ve francouzštině pomocí -iser (bitcoin-iser) a -er (bitcoin-er).

Analýza korpusů rovněž potvrdila četné užívání prefixoidů (makro-, mikro-, super-, hyper-, ultra- aj.), které byly použity například pro názvy dalších kryptoměn nebo jejich jednotek (superbitcoin, hyperbitcoin, microbitcoin, ultrabitcoin aj.). Protože je však jejich pravopis rozkolísaný (častěji se píší jako dvě oddělená slova, mnohdy i v podobě bitcoin ultra) a jedná se o názvy utvořené již v angličtině, v souhrnných tabulkách nejsou uvedeny, s výjimkou slova milibitcoin pro češtinu (z důvodu použití počeštěné podoby) a euro-bitcoin pro francouzský jazyk (vzhledem k použití jako adjektiva). Jak v češtině, tak i ve francouzštině se vyskytuje i řada sufixoidních kompozit, např. bitcoinman, bitcoinmánie / bitcoinmanie, bitcoinfobie / bitcoinphobie aj.

Obecně lze říci, že lexém bitcoin si v obou jazycích zachovává rysy výchozího jazyka, co se týče pravopisu (jelikož však slovo bitcoin přináší do češtiny nezvyklou kombinaci hlásek, vznikly i další dvě variantní psané podoby daného výrazu bitkoin a bitkojn, prozatím však s malou frekvencí výskytu) a výslovnosti, je ale zařazen morfologicky. Slovotvorná adaptace tohoto anglicismu se projevuje především tvořením slovotvornými postupy (derivací a kompozicí) od anglického základu slova, v ojedinělých případech i přejímáním slovotvorně utvářených pojmenování $\mathrm{z}$ angličtiny (jako tomu bylo např́klad u slova bitcoiner).

\section{BIBLIOGRAFIE}

Beránek, J. 2017. „Bitcoiny v Alze zafungovaly. Kryptoměnou platí především zákazníci z ciziny." [online] Lupa.cz, 15. 6. 2017 [cit. 3. 7. 2018]. Dostupné z: https://www.lupa.cz/ aktuality/bitcoiny-v-alze-zafungovaly-kryptomenou-plati-predevsim-zakaznici-z-ciziny/ vlakno/2/.

Buzássyová, K. 2010. „Vztah internacionálnych a domácich slov v premenách času." Jazykovedný časopis 61 (2): 113-130.

Čermák, F. 2010. Lexikon a sémantika. Praha: Nakladatelství Lidové noviny.

Čermák, F., J. Filipec. 1985. Česká lexikologie. Praha: Academia. 
Fillner, K. 2014. „Jak na bitcoin. Krok za krokem.“ [online] Btctip, aktualizováno 2. 10. 2017 [cit. 25. 6. 2018]. Dostupné z: https://btctip.cz/wp-content/uploads/2018/05/jakna-bitcoin-karel-fillner-aktualizace.pdf.

Fridrichová, R. 2013. „O identitě anglicismů v metropolitní a québecké francouzštině." Pp 41-54 in I. Mišterová, E. Skopečková (eds.). A Search for Identity in Linguistic, Literary, Cultural and Historical Perspectives. Plzeň: FF ZČU.

Furdík, J. 2004. Slovenská slovotvorba. Prešov: Náuka.

Goursau, H. 2015. Dictionnaire des anglicismes. Saint-Orens-de-Gameville: Éditions Henri Goursau.

Grepl, M., Z. Hladká, M. Jelínek. 2008. Příručka mluvnice češtiny. Praha: Nakladatelství Lidové noviny.

Hill, K. 2014. Secret Money: Living on Bitcoin in the Real World. Jersey City: Forbes Media.

Hlavenka, J. 2013. „BitCoin se může stát zárodkem něčeho opravdu velkého. “ [online] Lupa.cz, 2. 5. 2013 [cit. 3. 7. 2018]. Dostupné z: https://www.lupa.cz/clanky/jiri-hlavenkabitcoin-se-muze-stat-zarodkem-neceho-opravdu-velkeho/nazory/?opl-order $=$ insert\&do= opl-reorder.

Horová, H. 2014. „Porozumění francouzskému odbornému textu v kurzech pro vysokoškolské studenty (nefilology) na základě využití elementárních znalostí lexikologie." Acta Fakulty filozofické Západočeské univerzity v Plzni 6 (1): 176-192.

iDNES.cz. 2018. „Bitcoin přežil, jiné měny ne. Investoři věří blockchainu." [online] iDNES.cz, 3. 7. 2018 [cit. 4. 7. 2018]. Dostupné z: https://ekonomika.idnes.cz/bitcoinblockchain-burza-kryptomeny-dvx-/eko-zahranicni.aspx?c=A180702_165823_ekozahranicni_rts.

Karlík, P., M. Nekula, J. Pleskalová. 2002. Encyklopedický slovník češtiny. Praha: Nakladatelství Lidové noviny.

Kolektiv. 2015. Le Grand Larousse illustré 2016. Paris: Larousse.

Kraus, J. a kol. 2005. Nový akademický slovník cizích slov. Praha: Academia.

Légifrance. 2018. „Vocabulaire de l'informatique (liste de termes, expressions et définitions adoptés)." [online] Légifrance. [cit. 30. 6. 2018]. Dostupné z: https:// www.legifrance.gouv.fr/affichTexte.do?cidTexte

=JORFTEXT000034795042\&dateTexte=\&categorieLien=id.

Martincová, O. 2017. „Internacionalismus. “ [online] P. Karlík, M. Nekula, J. Pleskalová (eds.), CzechEncy - Nový encyklopedický slovník češtiny [cit. 30. 6. 2018]. Dostupné z: https://www.czechency.org/slovnik/INTERNACIONALISMUS.

Martincová, O. a kol. 2004. Nová slova v češtině. Slovník neologizmů 2. Praha: Academia. Martincová, O. a kol. 2005. Neologizmy v dnešní češtině. Praha: ÚJČ AV ČR.

Massonnaud, R. 2014. „Le bitcoin intéresse le ministère des Finances. “ [online]. L'Express Votre Argent, 6. 8. 2014 [cit. 3. 7. 2018]. Dostupné z: https://votreargent.lexpress.fr/ impots/le-bitcoin-interesse-le-ministere-des-finances_1583825.html.

Mišterová, I. 2017. „Madijó? Madi ágerikum. Jazyk jako nositel kulturních hodnot v románu Arundhatí Royové Bůh maličkosti. " Acta Fakulty filozofické Západočeské univerzity v Plzni 9 (2): 139-152.

Mortureux, M.-F. 1997. La lexicologie entre langue et discours. Paris: CEDES.

Prouvost, J., J.-F. Sablayrolles. 2003. Les néologismes. Paris: PUF.

Radimský, J. 2003. Italské a vybrané francouzské neologismy z oblasti informatiky a nových médii (1990-1996). České Budějovice: Jihočeská univerzita v Českých Budějovicích, Pedagogická fakulta. 
Rejzek, J. 1993. „K formální adaptaci anglicismů. “ Naše řeč 76 (1): 26-30.

Reverso-Softissimo. 2017. „Bitcoin.“ [online] Reverso Dictionnaire [cit. 2. 7. 2018]. Dostupné z: https://dictionnaire.reverso.net/francais-definition/bitcoin.

Rey-Debove, J., A. Rey. 2005. Le Petit Robert de la Langue Française 2006. Paris: Dictionnaires Le Robert.

Soukup, T. 2013. „Do Oxfordského slovníku angličtiny se dostal Bitcoin, BYOD i phablet." [online] Czech New Center, 4. 9. 2013 [cit. 30. 6. 2018]. Dostupné z: https:// www.zive.cz/bleskovky/do-oxfordskeho-slovniku-anglictiny-se-dostal-bitcoin-byod-iphablet/sc-4-a-170402/default.aspx.

Steemit.com. 2018. „Bitcoin bublina a bitcoin mánie." [online] Steemit [cit. 3. 7. 2018]. Dostupné z: https://steemit.com/busy/@krakonos/bitcoin-bublina-a-bitcoin-manie.

Stroukal, D., J. Skalický. 2015. Bitcoin: Peníze budoucnosti. Historie a ekonomie kryptoměn, stručná př́ručka pro úplné začátečníky. Praha: Ludwig von Mises Institut CZ\&SK.

Svobodová, D. 2007. Internacionalizace současné slovní zásoby. Ostrava: Ostravská univerzita.

Svobodová, D. 2009. Aspekty hodnocení cizojazyčných přejímek: mezi módností a standardem. Ostrava: Ostravská univerzita.

Svobodová, D. 2013. „Psané podoby přejatých slov. " Bohemistyka 13 (1): 7-14.

Šabršula, J. 1983. Základy francouzské lexikologie. Praha: Státní pedagogické nakladatelství.

TLFi. 2018. „Anglicismus." [online] ATILF - CNRS \& Université de Lorraine. [cit. 28. 6. 2018]. Dostupné z: http://stella.atilf.fr/Dendien/scripts/tlfiv5/advanced.exe?8;s= 250701975.

Unesco.uniba.sk. 2017a. „Bitcoin.“ [online] Araneum Bohemicum III Maximum [cit. 5. 7. 2018]. Dostupné z: http://unesco.uniba.sk/aranea/run.cgi/freqs?q=aword\%2C\%5Blc\%3D $\% 22 . \% 2$ Abit.oin. $\% 2 \mathrm{~A} \% 22 \% 5 \mathrm{D}$; corpname=AranBohe_a\&viewmode=kwic\&attrs=word \& ctxattrs $=$ word \&structs $=$ doc $\% 2 \mathrm{Cp} \% 2 \mathrm{Cg} \& \mathrm{refs}=\% 3 \mathrm{Ddoc}$. urldomain\&gdexconf $=\&$ attr tooltip $=$ nott;fcrit $=$ word $/ \mathrm{e}+0 \sim 0 \% 3 \mathrm{E} 0 ; \mathrm{ml}=1$.

Unesco.uniba.sk. 2017b. „Bitcoin.“ [online] Araneum Francogallicum II Maximum [cit. 5. 7. 2018]. Dostupné z: http://unesco.uniba.sk/aranea/run.cgi/freqs?q=aword $\% 2 \mathrm{C} \% 5 \mathrm{Blc} \%$ $3 \mathrm{D} \% 22 . \% 2 \mathrm{Abitcoin} . \% 2 \mathrm{~A} \% 22 \% 5 \mathrm{D}$; corpname=AranFran a\&viewmode $=$ kwic\&attrs $=$ word \&ctxattrs $=$ word $\&$ structs $=\mathrm{doc} \% 2 \mathrm{Cp} \% 2 \mathrm{Cg} \& \mathrm{refs}=\% 3 \mathrm{Ddoc} \cdot$ urldomain \&gdexconf $=\&$ attr_tooltip $=$ nott;fcrit $=$ word $/ \mathrm{e}+0 \sim 0 \% 3 \mathrm{E} 0 ; \mathrm{ml}=1$.

Ústav pro jazyk český AV ČR. 2016. „Bitcoin.“ [online] Webové hnízdo LEXIKO Databáze heslárru [cit. 25. 6. 2018]. Dostupné z: http://lexiko.ujc.cas.cz/heslare/index.php ?word $=$ bitcoin\&full $=0 \&$ encode $=u t f 8 \_$general_ci\&psjc $=1 \& s s j c=1 \& s s c=1 \& s s c \_j m e n a=1$ $\& \mathrm{sn} 1=1 \& \mathrm{sn} 2=1 \&$ neomat $=1 \& \mathrm{spr}=1 \& \mathrm{svaz}=1$.

Veillet, T. 2017. „Nouveau verbe: «se faire bitcoiner»." [online] Investir.ch, 16. 6. 2017 [cit. 4. 7. 2018]. Dostupné z: https://www.investir.ch/2017/06/nouveau-verbe-se-fairebitcoiner/.

Wikislovník. 2017. „Bitcoin.“ [online] Wikislovník [cit. 2. 7. 2018]. Dostupné z: https:// cs.wiktionary.org/wiki/bitcoin.

Wiktionnaire. 2018. „Bitcoin.“ [online] Wiktionnaire [cit. 2. 7. 2018]. Dostupné z: https:// fr.wiktionary.org/wiki/bitcoin. 


\section{SUMMARY}

A simple computer program invented in 2008 by a computer scientist or group of engineers under the pseudonym Satoshi Nakamoto gave birth to the crypto-currency bitcoin, which has become the most famous and widely used virtual currency. Bitcoin is decentralized electronic money that is independent of banks and not regulated by governments. Lately, the number of merchants and places where this cryptocurrency can be used for payment has grown. Nonetheless, other virtual currencies like ether, ripple, litecoin or dash, known under the umbrella term "altcoins", have been continuously gaining a significant share of the market.

The constant rise of virtual currencies and blockchain technologies raises many questions to which various public institutions and citizens around the world hold contradicting standpoints. Even those who are not otherwise interested in finance, investment, or electronic culture express their opinions about bitcoin. However, the goal of this article is not to answer questions such as "what is bitcoin" and "how does it work"? "What are the risks or problems linked to the growth of virtual currencies?" In this paper, bitcoin is viewed purely from a linguistic perspective. The goal of the completed research is thus to analyze the Anglicism "bitcoin" in the Czech and French languages and show to what degree the term has been adapted in both languages.

Adaptation of loanwords is a complex process that develops at various language levels and depends on several factors (typology of languages, frequency of use, time factors, area of use, etc.). The research shows that the loanword "bitcoin" in Czech and in French preserves its original spelling and pronunciation. Thus, no graphic or phonological adaptation has taken place. Nonetheless, the term is shown to have adapted to the morphosyntactic system of Czech and French. It is attributed to the male gender in both languages, used in the plural, and has not been given any affixes or other components.

Derivation of substantives, primarily suffixal derivation, is characteristic for both languages. Primarily agent names (i.e. for those who buy, use, or handle bitcoin) are created by adding the suffixes -ár, -ér, -ista in Czech and-eur/-euse, -ien and-iste in French. In some cases, however, it is difficult to determine whether we are dealing with a derivation created in Czech or in French or an adapted loanword from English. Examples of this are words such as bitcoinizace (or in French bitcoinisation) or hyperbitcoinizace (in French hyperbitcoinisation), as both words also exist in English as well.

The majority of compounds that are found in the analyzed corpora or on the internet are nouns. Most often, they include composites made up of the word bitcoin and another English word. These compounds were not integrated into the summary tables. These tables primarily list examples of hybrid compounds linking the word "bitcoin" and a Greek element (makro-/macro-, mikro-/micro-, super-, hyper-, ultra-, -fobie/-phobie, -phile, euro-, etc.). Words compounded in this manner are often written in two ways: with a hyphen or as one word. Bitcoin has functioned as a means of payment for ten years. People use bitcoin to shop, as a store of value, or as savings; this cryptocurrency has also become a means of investment. Despite this fact, its fate is unclear and no one is able to predict its future. The fate of bitcoin as a currency can significantly influence its fate as a neologism in the given languages. Although this expression made its way into dictionaries of the French language in 2015 in book form (Le Petit Robert de la langue française, Larousse atd.), there is no guarantee that it will remain in the language, as new words especially in the area of new technologies appear rapidly and many of them just as quickly become obsolete. 